\title{
Intellectual Property in the 21st century in Ecuador
}

\author{
La Propiedad Intelectual del siglo XXI en Ecuador
}

\author{
Cynthia Mishel Gudiño Flores \\ Independent legal researcher \\ City: Ibarra \\ Country: Ecuador
}

Original article (research note)

RFJ, No. 8, 2020, pp. 59-71, ISSN 2588-0837

ABSTRACT: Intellectual Property is continuously present in
different manifestations of daily life. However, not all people
fully understand what this means, especially for authors of
artistic or scientific creations, or for inventors. Given this
scenario, it is essential to claim the role of the creator and its
economic impact on society; in order to increase the incentives
to materialize creative ideas of the human intellect that,
inevitably, contribute to the production of science and culture.

KEYWORDS: royalties, patents, Intellectual property, economic and social development, creativity.

RESUMEN: La Propiedad Intelectual está constantemente presente en diferentes manifestaciones de la vida cotidiana. Sin embargo, no todas las personas comprenden íntegramente lo que esto significa, sobretodo, para los autores de creaciones de índole artística o científica, o para los inventores. Dado este escenario, es importante reivindicar el rol del creador y su incidencia económica en la sociedad; con el fin de otorgar un mayor número de incentivos a la materialización de ideas creativas del intelecto humano que, inevitablemente, contribuyen a la producción de ciencia y cultura. 
PALABRAS CLAVES: derechos de autor, patentes, propiedad intelectual, desarrollo económico y social, creatividad.

\section{INTRODUCTION}

To deal with the subject of intellectual property is to enter, among others, the world of books, medicine, inventions, music, cinematography, television programs, and the radio. Every day people listen to music in the car on the way to work, read books, watch movies or videos, take medications, use a computer, or access a website. However, they do not always realize that the goods and services protected by the intellectual property are behind their simplest activities of daily life. Much less are they aware of the existence and needs of the creator of all these inventions and works, which imply a series of intellectual property rights?

In order to financially reward the effort to create goods and services, people are obliged to pay compensation for their daily use. Otherwise, there would be no motivation to continue investing time and money in works or inventions that will immediately go into the public domain without actually generating a direct economic benefit to its creator. (Bercovitz, 2015)

Although it is true, in the field of intellectual property protection, two high currents of thought are very well marked by different concepts. The basic idea of the first holds that inventions and creations of any kind should not be protected if they undermine the collective use that can be made of them. This position understands that intellectual property rights are below free access to goods and services. Therefore, it prioritizes their use and not the protection of those who created them. (Stiglitz, 2017)

On the other hand, the second trend indicates that as the author is the raw material for the creation of any work, he deserves to have an incentive that motivates him to continue externalizing forms of expression of knowledge. As intellectual property is the accumulation of culture, of its forms of generation and diffusion; and, above all, a sizeable active part of 
the market, a space in which goods and services are exchanged, the continuous generation of knowledge is of importance and collective interest. (Antequera, 2007)

In this order of ideas, the present research article elucidates all the questions that arise regarding the economic impact of the protection of intellectual property at the national level, and the incentives that can be generated in innovation and generation. of knowledge through correct legislation and application of the patent and copyright regime.

\section{PRELIMINARY CONSIDERATIONS}

The concept of an author refers to the natural person who creates a work and that as a consequence, he has immediate intellectual property rights over it. Therefore, according to the thesis of the birth of the right along with that of the work. In this sense, the author is not only the original purchaser of the right, but also the exclusive full owner of the intellectual property. (Bercovitz, 2015)

According to the preliminary ruling 32-IP-97 of the Andean Community Court of Justice (1998), copyright is compatible with industrial property rights and, at the same time, independent of them. And vice versa. So, independence and compatibility can be simultaneous with the protection of the same intellectual property.

In this sense, the photographic memory of an industrial invention can qualify as a work in the field of copyright due to its original form of expression; An artistic manifestation can be useful to identify products or services typical of trademark law; and even, an original commercial motto could qualify as a literary work. (Antequera, 2007)

Then there is no discussion, but instead regarding the strength and extent of the protection granted to them. As previously noted, there are two firm and divergent theories regarding the protection of intellectual rights. 
The first theory considers that it is a grave mistake to try to maximize profits for a few (understood authors and industries) instead of maximizing the community's development and well-being. He understands that market dynamics are changing, and that emerging economy has a responsibility to create a new intellectual property system that is fair and that recognizes the need for access to knowledge to achieve a community with optimal levels of development and growth.

The maxim of this posture is to achieve a recommended level of well-being in all people, ahead of corporate or personal profits or revenues. Hence, it follows that it does not attach importance to the production of knowledge if it is useful application is not allowed in various fields such as the doctor, the pharmacist, or the recreational. (Jayadev, 2017)

To clarify the meaning of this trend, patents, considered in the Ecuadorian legal system within the Organic Code of the Social Economy of Knowledge, Creativity, and Innovation (Ingenios Code, 2016), will be taken as a tool designed with the purpose to promote industrial and technological development to achieve adequate standards of good living. According to Baker (2017), within the developed position, the patent system is an awarding mechanism that prevents the correct flow of knowledge, minimizes the benefits or profits derived from the said award, and distorts the economy.

The solution, it is proposed, is an alternative that maximizes the flow of knowledge through a collective creative space such as open-source software. Since copyright is understood, and even more so, the patent system creates cognitive monopolies that prevent access to knowledge, the satisfaction of the primary needs of emerging markets, and health, placed on basic human needs.

The main problem, caused by strong positions and discussions at the global and internal levels, is the conception of knowledge as a public good that affects economic and social levels. The concern arises because the market chooses to 
provide insufficient knowledge due to the lack of incentives for research purposes. (Diagram 1)

Diagram 1: Market, knowledge and the lack of incentives
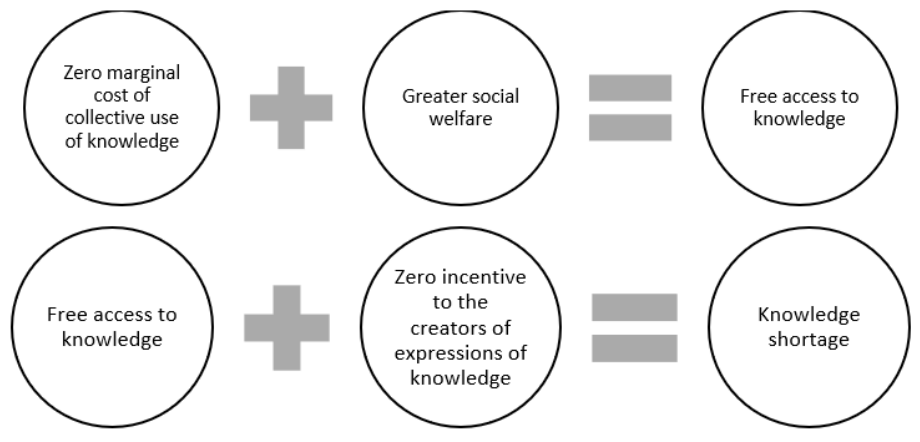

Source: Bercovitz, R. (2015).

Prepared by Cynthia Gudiño

Throughout the entire previous century, the theory put forward indicates that it was thought that this market failure could be solved through another: private monopolies. The patents and all the intellectual rights belonging to the inventions, works, or creations were applied for this purpose. However, according to Stiglitz (2017), the protection of intellectual property has managed to become a real problem, or a problematic solution, to solve the dilemma of promoting and financing research.

Through this protectionist system of the author and the industries, research has not been directed at innovation or the creation of new products, but rather, it has only been intended to expand monopoly power until achieving a total monopolization of the market, easily granted through a patent. (Baker, 2017)

A clear example of this is the judgment of the United States Supreme Court in the Association for Molecular Pathology v. Myriad Gentis, Inc case (2013), in which it is made 
clear that natural genes are not susceptible to being patented. Through this, it can be analyzed whether or not patents stimulate research and innovation. The results are unequivocal because innovation accelerated, research multiplied, and better diagnostic tests were implemented to determine, for example, the presence of certain types of genes related to breast cancer. All this, at much lower costs and thanks to the non-application of the industrial property protection system.

Finally, in the same line of thought, this theory considers that the current intellectual property regime is unsustainable because the 20th century's economy is different from that of the 21st century in several respects. Besides, it ensures that an open system of knowledge should be the rector of creations and inventions, but the world has chosen a different system. According to Jayadev's (2017) thinking, the prevailing intellectual property regime has created a diversity of barriers to access and application of knowledge, creating a large gap between private and social profits.

However, all this established scheme breaks down due to the development of the second position that has a different approach, despite also accepting the need to invest in the socalled weightless economy, which involves science, research, innovation, and technology. However, it addresses this need differently since it gives greater emphasis to the author and his right to receive compensation for the creation made. This theory understands that the protection of the general welfare and the collective access to knowledge does not make sense if there are no productions protected through patents or copyrights (Gallastegui, 2008). That is, if no content can be accessed.

The stagnation, both of production and of access to knowledge, which may occur as a consequence of the lack of application of practices that benefit the author and protect his intellectual and industrial property rights, is extremely dangerous and counterproductive because the disincentive it generates can reach be so shocking that research and creation projects cease. 
The patent system needs to be approached from a vision that cares about the massive generation of knowledge. Authors, scientists, and discoverers are always interested in sharing their productions when they know that they will be rewarded for it and that, through this, they can become an economically sustainable way of life (Lipszyc, 2016). Otherwise, the creation of works or the discovery of cures for diseases or inventions of any kind would never be accepted as a valid source of income if access to knowledge is prioritized over its elaboration.

People are not motivated to produce if they know in advance that they will not receive any compensation. Currently, Ecuador does not have the highest levels of knowledge production in the world, despite the "Código de Ingenios" having made (insufficient) efforts to motivate innovation, the generation of ideas, and the creation of works. It is necessary to promote a culture of respect for the author and his intellectual and industrial property rights with greater force, through economic returns that gratify and reward researchers' work.

In the 21st century, the substantial changes that globalization has brought about make it necessary to rethink the existing forms of access to knowledge platforms that, in one way or another, break the strict framework established to protect the creator specifically. Moreover, they leave it in a vulnerable situation.

The containers of intellectual property rights are varied, and sometimes they get out of the control of the authors. As possible consequences of this fact, the decision not to produce more works, more books, more medicines, or even more ingenious inventions, because it is not profitable to support life. The impossibility of solving basic needs due to the absence of mechanisms that assure researchers and creators that they obtain the necessary financial compensation produces catastrophic effects at the level of cognitive production.

In this sense, the intellectual and industrial property ceases to become a source of income due to the few incentives it proposes, and which should be derived directly from innovation 
and knowledge generation. The problem is present, as has been shown, at the legislative and application level of the patent and copyright regime, which does not sufficiently motivate the content creator to do it as if it were directly their profession, because they do not grant the necessary property assurances on inventions or creations.

\section{PROTECTION OF INTELLECTUAL PROPERTY IN ECUADOR}

The excessive amount of technologies and transformations of all kinds: economic, social, cultural, and political; they are fundamental characteristics of the structure and development of the 21st century. At this time, the most determining factor of human knowledge, development, and well-being is the evolution of cognition through this fourth industrial revolution that has been developing: the technological revolution.

Access to all the knowledge contained in the internet network facilitates its application and places authors, creators, and scientists dedicated entirely to the research and production of new forms of knowledge at a disadvantage. Although this is a public domain asset, authors should be the main subject of protection and not vice versa. (Bercovitz, 2015)

In Ecuador, property rights are protected in just 35.9\%, which means that more than half of these types of rights are left unprotected. On the other hand, developed, comprehensive, and protectionist legislation on the right to private property, such as that of Norway and the United States, a level of protection of $86.1 \%$ and $79.3 \%$ is reached (Index of Economic Freedom, 2019). These data are essential to consider since they directly affect areas such as freedom of business and investment.

Thus, in countries that manage a robust system of protection of intellectual and industrial property rights, the levels of investment, creation, and development are higher, since there is a guarantee for the creator of possession, use, and usufruct of themselves. In this type of system, is enhanced 
the participation of a person or company in the process of creating or expressing knowledge. Finally, if the author is not protected, there will be no interest in generating or investing in knowledge, and consequently, nothing can be accessed, and nothing can be applied.

Following this argumentative line, Graph 1 describes the data related to freedom of investment.

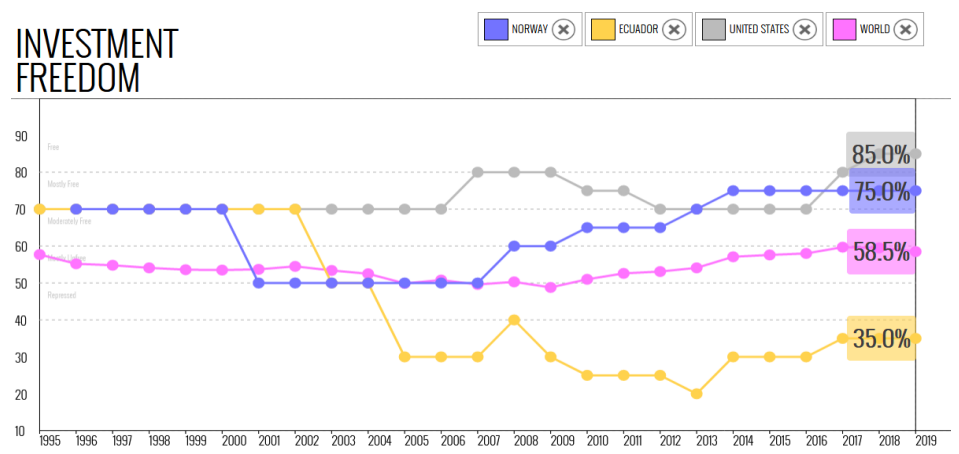

Source: Index of Economic Freedom (2019).

Graphically, Norway, and the United States are countries with high investment percentages, $75 \%$, and $85 \%$, respectively. Besides, there is not a coincidence that they are also the same countries that grant more excellent protection to property rights. This scenario reflects that citizens in those countries feel the freedom and confidence to make investments of any kind because their property rights are duly protected by legal bodies, where private property is prioritized over the collective property.

Thus, they decided to invest in research projects destined for specific purposes: medicines for specific diseases, beneficial and innovative inventions, creations, books, and others. In this way, people feel supported at the normative level to undertake activities that allow them to generate a more significant amount of knowledge, and they also feel motivated when receiving financial compensation for the achievements they have achieved in their research area. How obtaining basic enough income to live is a reality for them; they keep creating content. 
Meanwhile, in Ecuador, investment freedom is shallow, just $35 \%$. While it is true, this is due to multiple factors, but the protection of property rights is undoubtedly one of them. Because the private property is not sufficiently protected in this country, people are not willing to make investments of any kind, even less in the research field, because they know that their rights will not be duly respected or remunerated.

In the specific case of intellectual property, the level of protection that Ecuadorian law has granted to rights continues to be insufficient. By prioritizing access to information, over the generation of knowledge, it is discouraging to large companies that want to Invest in research topics. Authors interested in generating the content of a different nature.

Likewise, data similar to those already mentioned are reflected in the field of freedom of company or business. In Ecuador, this parameter only covers $54.1 \%$, while in Norway, it covers $89.4 \%$, and in the United States, $83.8 \%$ (Index of Economic Freedom, 2019). These percentages are highly relevant if the aim is to accurately understand the scope of protection of property rights in general and intellectual property. With weak legislation that fails to promote research or the development of knowledge in any form, people are not free to conduct business that they would consider relevant to the advancement and evolution of artifacts, inventions, scientific discoveries, and others.

In this way, the freedom of investment and business reflect the reality of the protection of intellectual and industrial property rights that a country has. These factors are directly proportional, and in the Ecuadorian case, the creator's leading role as the raw material of any good or service that is the object of intellectual property law should be emphasized even more. 


\section{CONCLUSIONS}

Throughout all the work, the need to pay more considerable attention to legislative policy becomes evident, mainly because there are currently various forms of production and access to knowledge that, on occasions, can be violated the intellectual or industrial property rights of its most direct owners: the creators.

A system that advocates free access to knowledge and all its forms of expression will eventually reach a point of stagnation and recession. On the other hand, a system that motivates, encourages, and rewards the author, will achieve greater varied and constant cognitive production. Consequently, the first system, sooner or later, will have no new content to access, while the second system will always possess innovative knowledge, goods, and services because the creators will be predisposed to elaborate them due to the benefits they represent.

It has been made clear that the intellectual property protection system has a direct impact on a country's economic environment, and that knowledge generation is a direct source of income. However, the problem lies in the lack of incentives to the author and the excessive protection of collective access to the various forms of expression of knowledge. All this produces adverse effects on scientific and cultural knowledge due to the setback or stagnation.

As demonstrated through various documentary sources, the genuinely optimal thing is not to deprive the creator of the rights that correspond to him as such, by guaranteeing free access to his form of cognitive expression. Instead, it is advisable to protect it so that it continues to research and produce based on parameters of innovation, utility, and creativity. It allows subsequent access to high-quality goods and services that contribute to achieving collective wellbeing, without forgetting that the real object of protection of the intellectual and industrial property right is the form of expression of knowledge, and not this in itself. 


\section{REFERENCES}

Antequera, R. (2007). Los principios clásicos del derecho de autor $y$ las nuevas tecnologías. Madrid, España.

Asamblea Nacional del Ecuador. Código Orgánico de la Economía Social de los Conocimientos, Creatividad e Innovación. [Cod.]. (2016). R. O. 899, 09 December 2016.

Bercovitz, R. (2015). Manual de propiedad intelectual. Madrid, España.

Espín, A. (2014). Propiedad intelectual en el siglo XXI, nuevos continentes y su incidencia en el derecho de autor. Madrid, España: Editorial Reus.

Gallastegui, M. (2008). Economía sin peso. Europa Euskadi, (236), (pp. 3-4).

Jayadev, A., Baker, D. y Stiglitz, J. (October 2017). Propiedad Intelectual para la economía del siglo XXI. Nueva Sociedad. Retrieved from: https://nuso.org/articulo/ propiedad-intelectual-para-la-economia-del-siglo-xxi/

Lipszyc, D. (2016). Aspectos que componen la Propiedad Intelectual. Madrid, España: Advocatus.

Lipszyc, D. (2016). Panorama del dominio público oneroso (o pagante) en materia de derecho de autor. Utilidad, incomprensión y resistencia. Anuario Dominicano de Propiedad Intelectual, ISSN 2410-3640, (3), (pp. 17-37). Retrieved from: https://dialnet.unirioja.es/servlet/ articulo? codigo $=6095920$

Stiglitz, J. (2003). La transición de una economía regulada a una economía de mercado. Revista de Ciencias Empresariales y Economía, 2, (pp. 18-32). Retrieved from: https:// dialnet.unirioja.es/servlet/articulo? codigo $=2538295$ 
The Heritage Foundation. (2019). 2019 Index of Economic Freedom. Retrieved from: http://www.iberglobal.com/ files/2019-1/economic_freedom_index_2019.pdf

Received:: 25/03/2020

Approved: 30/10/2020

Cynthia Mishel Gudiño Flores: Independent legal researcher Email: cynthigf98@gmail.com

City: Ibarra

Country: Ecuador 
